\title{
BIODIVERSITY AND TRADITIONAL SHEEP GRAZING IN THE SOUTH BANAT REGION
}

GRDOVIĆ SVETLANA, SAVIĆ MILA, BEČKEI Ž and DIMITRIJEVIĆ B

University of Belgrade, Faculty of Veterinary Medicine, Serbia

(Received 22nd July 2012)

In this paper the capacity for reintroduction of traditional sheep breeds as key resources for biodiversity conservation systems in HNV farming system of the South Banat region was analyzed. Taking the vulnerability of the ecosystem into consideration when creating the optimal grazing system based on traditional rearing breeds, can contribute to the protection of biodiversity in the South Banat region. The representatives of Fabaceae, Poaceae, Lamiaceae, Rosaceae and Apiaceae family were described. Basic nutritive components of pasture and mixed hay: crude moisture, crude ash, crude protein, crude fat, crude cellulose, calcium (Ca), magnesium $(\mathrm{Mg})$, phosphorous $(P)$, copper (Cu), iron (Fe), manganese (Mn) and zinc (Zn) were measured.

Botanical analysis has confirmed the presence of plant diversity, as well as the nutritive value of sheep pastures. Chemical analyses of samples pointed out that the levels of crude proteins, cellulose, fats, macro and trace elements are sufficient to satisfy the requirements of low input sheep farming system and therefore can be considered a solid base for reintroduction of autochthonous sheep breeds in the peripheral parts of the Deliblato Sands area.

Key words: biodiversity, grassland farming, native breeds, traditional management

\section{INTRODUCTION}

Intensive agricultural practice, the use of fertilizers and pesticides and the presence of high densities of grazing livestock, greatly affect species and habitat diversity. As a response to the negative effects of intensive agricultural production in Europe, a new concept of High Nature Value farming systems in terms of biodiversity and management practices has been introduced (Baldock et al., 1999). High Nature Value farming systems are basically low intensity farming systems, which are closely intertwined with the natural habitat in order to contribute to preservation of endangered species and habitats.

The main characteristics of HNV farming have been developed through projects undertaken under patronage of the European Environment Agency (Andersen et al., 2003), the Institute for European Environmental (2007), PanEuropean Study (Billeter et al., 2008) and European Commission for Agriculture 
and Rural Development (2009), and they showed that low-intensity farming may bring forth significant levels of biodiversity. HNV farmland covers around $30 \%$ of the European farmed area (Kazakova et al., 2011). This type of farmlands is mostly found in South and East Europe (Paracchini et al., 2008). The South and East Europe region is considered to be the "green gold" of Europe and the "green lungs" of Europe. The South Banat region in Serbia, (partially covered by Deliblato sands) has a potential to be High Nature Value farming system. The Region was well known for its high degree of plant biodiversity and endemism, associated with the fragile ecosystem characteristics (Cooper et al., 2010). The results of this study implicate the diminution of biodiversity. One of the key factors of the reduction of biodiversity is limited application of traditional extensive livestock production in the region. The species richness and nature conservation value of grasslands decreases after abandonment, while invasive species spread and natural habitats disappear. Positive effects of traditional livestock grazing and mowing on plant species richness in Europe have been reported in numerous studies (Pykala, 2005; Dumont, 2007; Hoste, 2011). Use of traditional instead of commercial breeds has frequently been recommended to meet biodiversity and production goals in sustainable grazing systems in Europe (Isselstein et al., 2007). Their high environmental value has been recognized (Marguerat, 2011; Smal, 2011).

Taking the vulnerability of ecosystems into consideration when creating the optimal grazing system based on traditional rearing breeds, can contribute to the protection of biodiversity in the South Banat region. Tsigai and Zackel type Vlashko-Vitoroga sheep are autochthonous breeds well adapted to the variability of climatic, geological and topographic factors, and their high value for nature conservation has been recognized. As for the highly selected exotic breeds, they have selective advantage rearing under low intensity livestock practice in the South Banat region.

In order to analyze synergies of animal resource management and High Nature Value farming systems, the objective of this study was to evaluate the grazing resources of sensitive habitats, as well as the capacity for reintroduction of autochthonous sheep breeds in the peripheral parts of the Deliblato Sands area.

\section{MATERIALS AND METHODS}

\section{Analyses of botanical composition}

The research took place in the South Banat region, in Bela Crkva and Kovin municipalities, partly covered by Deliblato Sands - the biggest sandy terrain in Europe, originating from a prehistoric desert.

Forage samples from the South Banat South region were taken in a period from April to October 2011. Eight samples (each from pasture and mixed hay) were analyzed. Hay was properly conserved, all parts of the plant were preserved which has enabled exact botanical analyses. Plants species were determined by floral determination key (Flora Srbije VIII, 1976; Javorka and Csapody, 1991). Determined species were sorted into classes according to their nutritious value. 
Acta Veterinaria (Beograd), Vol. 62, No. 5-6, 709-716, 2012.

Grdović Svetlana et al.: Biodiversity and traditional

sheep grazing in the South Banat region

Based on its organoleptic and chemical properties, hay quality was determined, consecutively scored and classified according to Leinkeit (1969).

Analyses of chemical composition

Hay samples were collected according to procedure AS-1064 (1993). The content of crude ash, crude protein, crude fat and crude cellulose was determined in relation to dry matter. Sample preparation for analyses was done according to AOAC (1990). Determination of basic nutritive components was done according to the following procedures: crude moisture SRPS ISO 6496/2001; crude ash SRPS ISO 5984/2002; crude protein SRPS ISO 5983/2001; crude fat SRPS ISO $6492 / 2001$; and the content of crude cellulose according to accredited laboratory method (DM1). The content of calcium (Ca) and magnesium (Mg) was determined by SRPS ISO 6869/2004 and phosphorous (P) by spectrophotometry. The content of trace elements, copper $(\mathrm{Cu})$, iron $(\mathrm{Fe})$, manganese $(\mathrm{Mn})$ and zinc $(\mathrm{Zn})$ was determined by atomic absorption spectrophotometry according to SRPS ISO 6869/2004.

Presence of aflatoxins (B1 +G1) was investigated by enzyme linked immune assay ELISA, IHM-03-007. The presence of organochlorine pesticides (hch, lindane, aldrine and dieldrine, heptachlor and heptachlor dioxide, DDT, endrine, endosulphane) was determined by gas chromatography according to the procedure GC-ECD, IHM-03-002.

All mentioned procedures comply with the Rule Book for Feed Sampling and Analyses (SI. list SFRJ br. 15/87), as well as with Animal Feed Rule Book (SI. glasnik RS 41/09).

Statistical analyses

A statistical analysis of samples was done by GraphPad Prism, descriptive statistical parameters were used (Xsr, SD and CV).

\section{RESULTS}

Floristic composition of the fresh plants from the pastures of the analyzed area has shown the presence of a high number of species, which implies high diversity of this habitat, as well as a variety of possibilities for production.

From Fabaceae family the following species were present: Trifolium repens L., Medicago sativa L., Lathyrus sativum L., and Lotus corniculatus L. Presence of the following species from Poaceae family was revealed: Lolium perenne L., Agropyrum repens (L.) P.B., and Festuca ovina L. The following species are widespread as well: Glechoma hirsuta Waldst.\& Kit., from family Lamiaceae, Potentilla reptans L., from family Rosaceae and Peucedanum arenarium Waldst.\& Kit., as a representative of Apiaceae family. Medical herbs, such as: Achillea millefolium L., Althaea officinalis L., Hypericum perforatum L., Malva silvestris L., Matricaria chamomilla L., Mentha aquatica L., Origanum vulgare L., Plantago major L., Tanacetum vulgare L., Taraxacum officinale L., and Thymus serpyllum L., were also present. 
The presence of grass species of high nutritional value was determined by botanical analyses in the samples of the pasture, as well as in the mixed hay samples. Predominant species in the mixed hay samples were Trifolium repens L., and Medicago sativa L. Species determined in the mixed hay samples were classified, according to their nutritional value, into first class. All mixed hay samples were of a pleasing aroma, green in color and without a notable presence of dust or smack and were classified into second class of hay (hay of good quality). Chemical composition of hay and pasture samples is shown in Table 1. Presence of mycotoxins and pesticides is shown in Table 2.

Table 1. Chemical composition of hay and pasture samples

\begin{tabular}{|c|c|c|c|}
\hline \multicolumn{2}{|c|}{ Parameter } & Mixed hay & Pasture \\
\hline \hline Moisture & Xsr \pm SD & $9.82 \pm 0.62$ & $74.53 \pm 4.52$ \\
(\% DM) & CV\% & 6.33 & 6.07 \\
\hline Crude cellulose & Xsr \pm SD & $40.22 \pm 1.49$ & $8.93 \pm 0.95$ \\
(\% DM) & CV\% & 3.71 & 0.34 \\
\hline Crude ash & Xsr \pm SD & $6.58 \pm 0.28$ & $2.86 \pm 0.20$ \\
(\% DM) & CV\% & 4.27 & 6.87 \\
\hline Crude protein & Xsr \pm SD & $6.47 \pm 0.30$ & $5.82 \pm 0.36$ \\
(\% DM) & CV\% & 4.70 & 6.22 \\
\hline Crude fat & Xsr \pm SD & $0.93 \pm 0.05$ & $1.67 \pm 0.23$ \\
(\% DM) & CV\% & 5.27 & 13.63 \\
\hline Calcium & Xsr \pm SD & $4094.88 \pm 159.42$ & $3282.50 \pm 243.20$ \\
(\% DM) & CV\% & 3.89 & 7.41 \\
\hline Phosphorus & Xsr \pm SD & $1026.30 \pm 78.87$ & $2292.75 \pm 214.94$ \\
$(\%$ DM) & CV\% & 7.67 & 9.37 \\
\hline Magnesium & Xsr \pm SD & $1499.50 \pm 95.44$ & $473.88 \pm 41.87$ \\
(\% DM) & CV\% & 6.36 & 8.84 \\
\hline Iron & Xsr \pm SD & $215.94 \pm 4.51$ & $283.43 \pm 23.38$ \\
(mg/kg) & CV\% & 2.09 & 8.25 \\
\hline Zinc & Xsr \pm SD & $16.99 \pm 0.73$ & $6.58 \pm 0.27$ \\
(mg/kg) & CV\% & 4.31 & 4.04 \\
\hline Manganese & Xsr \pm SD & $61.18 \pm 0.87$ & $14.55 \pm 0.62$ \\
(mg/kg) & CV\% & 1.36 & 4.24 \\
\hline Copper & Xsr \pm SD & $4.69 \pm 0.28$ & $2.29 \pm 0.22$ \\
(mg/kg) & CV\% & 5.87 & 9.76 \\
\hline & & & \\
\hline & & & \\
\hline
\end{tabular}

*DM - percentage of dry matter 
Acta Veterinaria (Beograd), Vol. 62, No. 5-6, 709-716, 2012.

Grdović Svetlana et al.: Biodiversity and traditional

sheep grazing in the South Banat region

Table 2. Presence of mycotoxins and pesticides in hay and pasture samples

\begin{tabular}{|l|c|c|c|}
\hline Organochlorine pesticides & Mixed hay & Pasture & Method deployed \\
\hline \hline Heksachlorobenzen (HCB) & $<0.010 \mathrm{mg} / \mathrm{kg}$ & $<0.010 \mathrm{mg} / \mathrm{kg}$ & GC-ECD, IHM-03-002 \\
\hline $\mathrm{HCH}$ (isomers alpha, delta \& beta) & $<0.010 \mathrm{mg} / \mathrm{kg}$ & $<0.010 \mathrm{mg} / \mathrm{kg}$ & GC-ECD, IHM-03-002 \\
\hline Lindan & $<0.010 \mathrm{mg} / \mathrm{kg}$ & $<0.010 \mathrm{mg} / \mathrm{kg}$ & GC-ECD, IHM-03-002 \\
\hline Aldrin and Dieldrin & $<0.010 \mathrm{mg} / \mathrm{kg}$ & $<0.010 \mathrm{mg} / \mathrm{kg}$ & GC-ECD, IHM-03-002 \\
\hline Heptachlor \& heptachlor-peroxides & $<0.010 \mathrm{mg} / \mathrm{kg}$ & $<0.010 \mathrm{mg} / \mathrm{kg}$ & GC-ECD, IHM-03-002 \\
\hline DDT \& derivates & $<0.010 \mathrm{mg} / \mathrm{kg}$ & $<0.010 \mathrm{mg} / \mathrm{kg}$ & GC-ECD, IHM-03-002 \\
\hline Micotoxines & & & \\
\hline Aflatoxins (B1+G1) & $<0.010 \mathrm{mg} / \mathrm{kg}$ & $<0.010 \mathrm{mg} / \mathrm{kg}$ & ELISA, IHM-03-007 \\
\hline
\end{tabular}

Analyses of mixed hay and pasture samples from the South Banat region showed that levels of hazardous and noxious substances were within the allowed values according to the regulations (Rule book, 02/90).

Floristic composition has shown the presence of legumes (Trifolium and Medicago spp.), which has many beneficial effects in low input sheep farming system as a high protein feed characterized by favorable amino acid composition and high digestibility. The impact of such forage on disease and pest life cycles, nitrogen fixation, increasing soil fertility and stability, biodiversity and landscape quality, has also been demonstrated (Ronchi, 2003; Radović, 2009). The chemical and nutritional forage characteristics are sufficient to satisfy nutritional requirements for sheep production in a low input system.

\section{DISCUSSION}

The South Banat region, Deliblato Sands and the peripheral parts of Deliblato Sands are an area which once was part of a prehistoric desert. Years of studies of biodiversity in this area have shown a great variability of plants, mammals and birds. The plant biodiversity in this area counts about 900 Cormophyta species, among which many are relict and rare species, endemic and subendemic, e.g. Paeonia officinalis L. subsp. banatica (Roch). Furthermore, Artemisia pancicii (Janka) Ronninger, Rindera umbellata (Waldst and Kit) Bunge, Fritillaria degeniana $\mathrm{H}$. Wagner, Prunus tenella Batsch, and Helichrysum arenarium (L.) Moench. The high levels of habitats' biodiversity is represented by 8 specific fitocenoses types: send fitocenoses (Corispermo-Polygonetum arenariae and Festucetum vaginatae deliblaticum), steppe fitocenoses (Koelerio-Festucetum wagnerii, Chrysopogonetum pannonicum and Festuco-Potentilletum arenariae), wet meadows fitocenose (Salicetum rosmarinifoliae and Molinietum coeruleae) and forest fitocenose (Querco-Tilietum tomentosae), (Stjepanović-Veseličić, L., 1953).

Results of the study "Developing a National Agri- Environment Program for Serbia" (Cooper et al., 2010; Kazakova et al., 2011) have shown that this region of 
Serbia can be considered a potential HNV system. The study has identified different factors which led to the deterioration of natural habitats and disappearance of certain species (Stevanović, 1999). The increasing utilization of marginal lands for crop production, reduction of nomadic systems, expansion of protected areas, are some of the reasons for the loss of interest in breeding of autochthonous sheep breeds.

Due to increasing abandonment of tradicional sheep farming, trees, shrub and other undesired plants such as: (Robinia pseudoacacia L. fam. Fabaceae, Crataegus monogyna Jacq. fam. Rosaceae, Celtis australis L. fam. Cannabaceae, Ailanthus altissima (Mill.) Swingle fam. Simaroubaceae, and Gleditschia triacanthos L. fam. Caesalpiniaceae) have taken over open spaces and reduced plant and animal biodiversity (Cooper et al., 2010). Reintroduction of autochthonous sheep grazing as a natural mean of management can be valuable to stimulate the diversity systems in conformity with the evolutionary history of the site (Smal, 2011). One of the most appropriate ways to revitalize and stimulate HNV farming system is by breeding of autochthonous Zackel type of VlashkoVitoroga sheep, which is well adapted to the traditional way of breeding and specific local environment.

Nowadays, Vlashko-Vitoroga sheep is an endangered population, registered at the Endangered - Maintained breeds list (DAD-IS 2012). Taking into consideration the FAO strategies for managing animal genetic resources, the characterization of Vlashko-Vitoroga sheep has been performed. The conservation breeding programmes are based on in situ conservation measures, keeping live animals on private farms. Vlashko-Vitoroga Zackel breed is a triple purpose, late maturing sheep, raised under low intensive management conditions. The prominent morphological characteristics of Vlashko-Vitoroga sheep are large and spiral-shaped vertically twisted horns, which makes this species very esthetically attractive and valuable in the promotion of this region.

Effects of low input sheep grazing depend on vegetation, soil characteristics, breed of grazing animal and grazing intensity (Marguerat, 2011; Dedeurwaerdere, 2011). Based on our findings pastures and meadows have shown the existence of a high degree of biodiversity. The dominantly present families are: Fabaceae family, Poaceae family, Lamiaceae family, Rosaceae family and Apiaceae family. The herbage feeding values are sufficient to satisfy requirements for sheep production in a low input system.

The positive interaction between extensive grazing and ecosystem biodiversity should contribute to the conservation program of autochthons breeds which are seen as a cultural heritage and which are bringing back the traditional landscape to the South Banat region.

\section{ACKNOWLEDGEMENTS}

This research was conducted within the project no: TR 31085 "Management of sustainable farming of organic lamb production as a support to rural development" financed by the Ministry of Education and Science of the Republic of Serbia. 
Address for correspondence:

Dr Svetlana Grdović

Faculty of Veterinary Medicine

University of Belgrade

Bulevar oslobođenja 18,

11000 Belgrade, Serbia

E-mail: cecag@vet.bg.ac.rs

\section{REFERENCES}

1. Andersen E, Baldock D, Bennett H, Beaufoy G, Bignal E, Brouwer F et al., 2003, Developing a High Nature Value Indicator, Report for the European Environment Agency, Copenhagen.

2. AOAC (Association of Official Analytical Chemists), 1990, Official Methods of Analysis of the Association of Official Analytical Chemists, Thirteenth Edition, Association of Official Analytical Chemists (publisher), Washington, DC 20044, USA, 1018.

3. AS-1064, 1993, Sampling Feed for Analysis.

4. Baldock D, 1999, Indicators for High Nature Value Farming Systems in Europe, In: F.M. Brouwer and J.R. Crabtree (Eds.) Environmental Indicators and Agricultural Policy. CAB International, Wallingford, UK.

5. Billeter R, Liira J, Bailey D, Bugter R, Arens P, Augenstein et al., 2008. Indicators for Biodiversity in Agricultural Landscapes: A Pan-European Study, J Appl Ecol, 45, 141-50.

6. Cooper T, Pezold T, Keenleyside C, Đorđević-Milošević S, Hart K, Ivanov S et al., 2010, Developing a National Agri-Environment Programme for Serbia. Gland, Switzerland and Belgrade, Serbia: IUCN Programme Office for South-Eastern Europe, 88.

7. DAD- IS, 2012, Domestic Animal Diversity Information System (FAO).

8. Dedeurwaerdere T, 2011, Evaluating Resource Use in Low Input Systems. First Lowlnput Breeds Symposium on Ethical Consideration in Livestock Breeding, Wageningen, Netherlands, March 15-16.

9. DM1, Određivanje sadržaja celuloze - dokumentovana akreditovana metoda Laboratorije Katedre za ishranu i botaniku.

10. Dumont B, Rook AJ, Coran Ch, 2007, Effects of livestock breed and grazing intensity on biodiversity and production in sustainable grazing systems, Grass Forage Sci, 62, 159-71.

11. European Commission Agriculture and Rural Development, 2009, The Application of the High Nature Value Impact Indicator, Guidance document 2007-2013.

12. Flora SR Srbije VIII, 1976, Srpska akademija nauka i umetnosti, Beograd.

13. Hoste Hervé, 2011, Improving "Low Input" Sheep Production Systems in Europe. First Low Input Breeds Symposium on Ethical Consideration in Livestock Breeding, Wageningen, Netherlands, March 15-16.

14. Institute for European Environmental, 2007, HNV Indicators for Evaluation, Final report for DG Agriculture, (Contract Notice 2006-G4-04), IEEP, London.

15. Isselstein J, Griffith BA, Pradel P, Venerus S, 2007, Effects of livestock breed and grazing intensity on biodiversity and production in grazing systems, Grass Forage Sci, 62, 145-58.

16. Javorka S, Csapody V, 1991, Iconographia florae partis austro-orientalis europae centralis, Akademiai Kiado, Budapest.

17. Kazakova Yanka, Stefanova Vyara, 2011, High Nature Value Farming in South-Eastern Europe: Policy Opportunities and Challenges in the EU Accession.

18. Leinkeit W, (Ed.), 1969, Handbuch der Tierernährung, Zweiter Band: Leistungen and Ernährung. Verlag Paul Parey, Hamburg, Berlin, 1-52.

19. Magda D, Tichit M, Durant D, Lauvie A, Lécrivain E, Martel G et al., 2011, Livestock farming systems and ecosystem services: from trade -offs to synergies. Book of apstracts of the 62 Annual Meeting of the European Federation of Animal Science, No 17 pp163 Stavanger, 29 August-3 September. 
20. Marguerat C, 2011, Environmental value of animal genetic resources Book of abstracts of the 62 Annual Meeting of the European Federation of Animal Science No 17, pp 17. Stavanger 29 August -3 September.

21. Paracchini ML, Petersen JE, Hoogeveen Y, Bamps C, Burfield, vanSwaay C, 2008, High Nature Value Farmland in Europe. An Estimate of the Distribution Patterns on the Basis of Land Cover and Biodiversity Data. European Commission Joint Research Centre, Institute for Environment and Sustainability.

22. Pykälä J, 2005, Plant species responses to cattle grazing in mesic semi-natural grassland, Ecosyst Environ, 108, 109-17.

23. Radović J, Sokolović D, Marković J, 2009, Alfalfa-most important perennial forage legume in animal husbandry. Biotechnol Anima Husb, 25, 5-6, 465-75.

24. Ronchi $B$, Nardone $A, 2003$, Contribution of organic farming to increase sustainability of Mediterranean small ruminants livestock systems, Livest Prod Sci, 80, 17-31.

25. Smal RW, 2011, Potential for conservation of local livestock breeds trough delivery of ecosystem service, Book of abstracts of the 62 Annual Meeting of the European Federation of Animal Science, No 17, pp 73 Stavanger, 29 August-3 September.

26. Stevanović V, 1999, Red Book of Flora of Serbia 1 - extinct and critically endangered taxa, Ministry of Environment Protection of the Republic of Serbia, Faculty of Biology, University of Belgrade and Institute for Nature Protection of the Republic of Serbia.

27. Stjepanović-Veseličić L, 1953, Vegetacija Deliblatske peščare, Beograd: Srpska akademija nauka i umetnosti / SANU, posebna izdanja, tom. CCXVI, br.4.

\title{
BIODIVERZITET I TRADICIONALNI NAČIN ISPAŠE OVACA U JUŽNOBANATSKOM REGIONU
}

\author{
GRDOVIĆ SVETLANA, SAVIĆ MILA, BEČKEI Ž i DIMITRIJEVIĆ B
}

\section{SADRŽAJ}

Imajući u vidu osetljivost ekosistema, primena izbalansirane ispaše, bazirana na gajenju autohtonih rasa ovaca mogla bi da doprinese očuvanju biodiverziteta. $\bigcup$ ovom radu ispitivane su mogućnosti za reintrodukciju tradicionalnih rasa ovaca, kao ključnog resursa za zaštitu biodiverziteta u okviru poljoprivrednih sistema visoke prirodne vrednosti južnobanatskog regiona. $U$ tom cilju ispitivan je botanički satav i hranljiva vrednost paše i mešanog sena sa područja južnog Banata. Utvrđeno je prisustvo familija: Fabaceae, Poaceae, Lamiaceae, Rosaceae i Apiaceae. Određen je sadržaj osnovnih hranljivih materija u mešovitom senu i paši: vlaga, pepeo, proteini, mast i celuloza. Takođe je utvrđen sadržaj $\mathrm{Ca}, \mathrm{Mg}, \mathrm{P}$, $\mathrm{Cu}, \mathrm{Fe}, \mathrm{Mn}$ i Zn. Utvrđeni nivo štetnih materija (mikotoksina i pesticida) bio je u propisanim granicama. Botanički sastav je pokazao visok stepen diverziteta kao $\mathrm{i}$ visoku hranljivu vrednost biljaka, koja može u potpunosti da zadovolji potrebe ovaca u ekstenzivnom načinu gajenja i predstavlja dobru osnovu za reintrodukciju autohtonih rasa ovaca na rubnim delovima Deliblatske peščare. 